\title{
An elusive nasopharyngeal hamartoma in a neonate
}

\author{
K.L.Cook ${ }^{1}$, M.A.DiPietro ${ }^{1}$ and R. S. Bogdasarian ${ }^{2}$ \\ ${ }^{1}$ Department of Radiology, University of Michigan Hospitals and \\ ${ }^{2}$ Department of Otorhinoloaryngology, Reichert Health Building, St. Joseph Hospital, Ann Arbor, Michigan, USA
}

\begin{abstract}
A rare, elusive, mobile, pedunculated nasopharyngeal tumor in a neonate is described. The child was only intermittently symptomatic and the diagnosis was not made until 1 month of age.
\end{abstract}

\section{Case report}

The infant was a term female born without complication by spontaneous vaginal delivery. The child did well until her first feeding which resulted in an episode of apnea and cyanosis requiring intubation. Evaluation included negative direct laryngoscopy and a negative esophagram. She did well for 2 weeks but was then referred to our institution for evaluation of intermittent "choking and gagging" spells complicated by cyanosis with feeding. Her parents on one occasion saw a fleshy mass in the child's mouth which immediately disappeared.

Initial fluoroscopy during a barium esophagram revealed a large, pedunculated mass which moved between the nasopharynx and hypopharynx with swallowing (Fig. 1a, b). Shortly following this study, she became symptomatic with retractions and cyanosis requiring intubation to relieve respiratory obstruction. Direct visualization and excision of the mass which arose from the left lateral nasopharyngeal wall was subsequently performed. The pathologist described a $2.7 \times 1.2 \mathrm{~cm}$ pedunculated mass consisting of a core of skeletal muscle and subcutis covered with keratinizing squamous epithelium and well developed adnexal structures including fine hairs, diagnostic of a benign cutaneous hamartoma (Fig. 2).

\section{Discussion}

This case illustrates the importance of studying the pharynx during the esophagram in infants with respiratory distress. A review of the literature of nasopharyngeal teratoid tumors indicates, that with one exception [1], infants present very early, before oral feeding, with respiratory distress, often requiring life-saving maneuvers. In addition to the delayed presentation the diagnosis remained elusive and was overlooked for 1 month. The mass was highly mobile and remained in the nasopharynx, apparent-

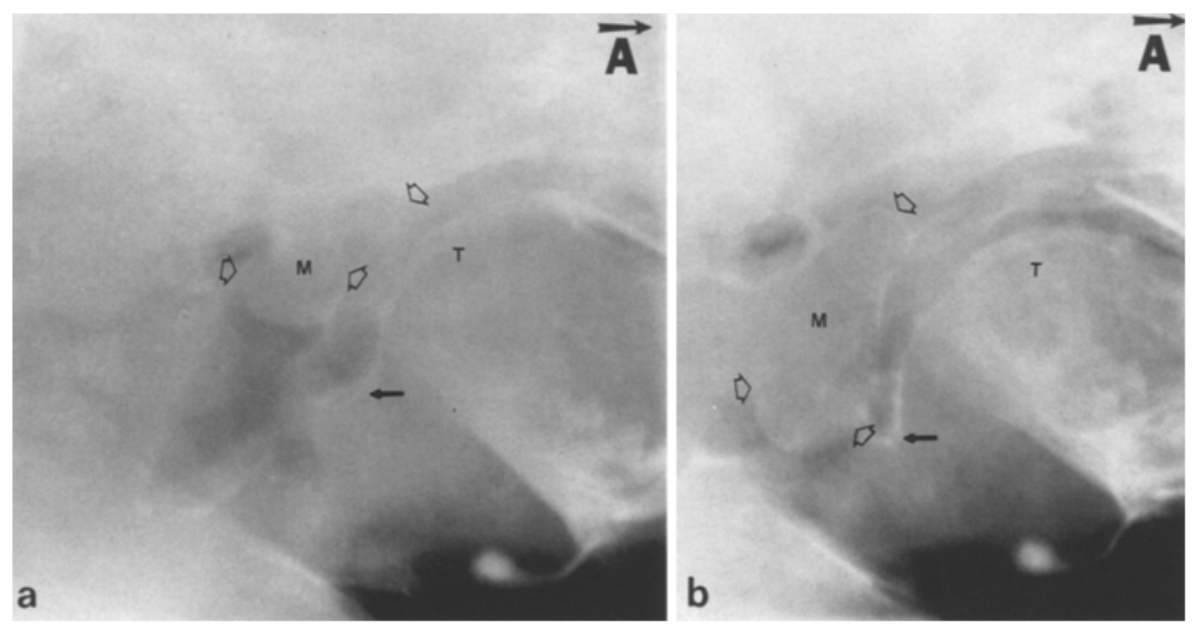

Fig. 1 a. Lateral spot films of barium coated pharynx with mass $(M$, arrowheads) retracted into nasopharynx, above the soft palate. b Mass has fallen into hypopharynx to level of aryepiglottic folds. $\mathrm{A}=$ anterior; $\mathrm{T}=$ tongue; solid arrow denotes vallecula 


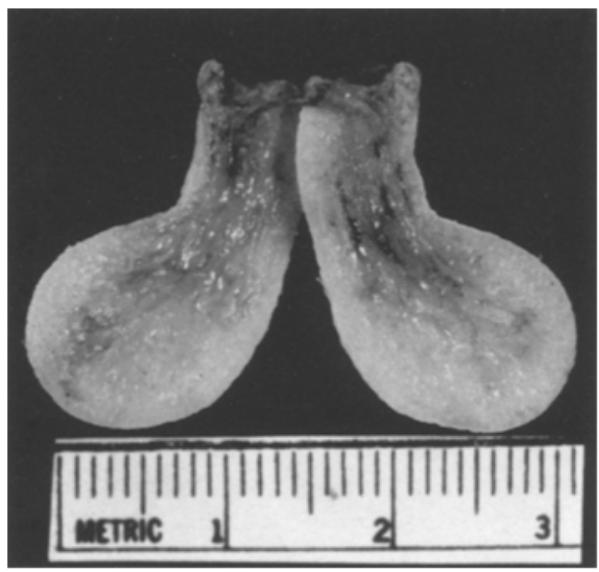

Fig. 2. Bisected gross specimen

ly superior to the soft palate during asymptomatic periods. With feeding, the pedunculated mass dropped into the hypopharynx, obstructing both the larynx and esophageal introitus.

Teratoid growths of the nasopharynx include those with tissue constituents not indigenous to that location: teratomas, composed of all three germ cell layers and dermoids, made up of ectoderm and mesoderm. Hamartomas, with well differentiated indigenous tissues comprise the remainder. In the nasopharynx, it is difficult to distinguish between these entities on the basis of constituent germ cell layers alone since embryologically, the nasopharynx is a junctional zone between ectodermal and endodermal mucosa [2]. Thus, review of multiple prior case reports reveals that "dermoid" and "teratoma" have been used interchangeably. Dermoids (or hairy polyps) are the most common; more than $50 \%$ present under 1 year of age, and there is a 6-7:1 predilection for females. Hamartomas and true teratomas are much more rare.

Acknowledgements. We thank K.McClatchey, M.D., Department of Pathology, and Laurie Hendrick, Secretary, Department of Radiology, University of Michigan.

\section{References}

1. Boies LR Jr, Harris D (1965) Nasopharyngeal dermoid of the newborn. Laryngoscope 75: 763

2. Zarbo RJ, McClatchey KD (1983) Nasopharyngeal hamartoma: report of a case and review of the literature. Laryngoscope 93: 494

Received: 13 May 1987; accepted: 6 June 1987

Dr. M.DiPietro

Section of Pediatric Radiology

University of Michigan Hospitals

Mott Children's Hospital C $3123 / 0252$

1500 E. Medical Center Drive

Ann Arbor, MI 48109-0252

USA

Literature in pediatric radiology (continued from p.350)

Renal growth in patients nephrectomized for Wilms tumour as compared to renal agenesis. Dinkel, E. et al. (Abt. für Rad. der Univ., Hugstetter Str. 55, D-7800 Freiburg, FRG) 147, 54 (1988)

Osteopathia striata, cranial sclerosis with cleft palate and facial nerve palsy. Kornreich, L. et al. (Dept. of Ped. Rad., Beilinson Med. Center, Petah Tiqva 49100, Israel) 147, 101 (1988)

Ultrasound findings in childhood chronic liver parenchymal diseases. Patel, P.J. et al. (Rad. Dept. (Box 40), King Khalid Univ. Hosp., P.O. Box 2925, Riyadh 11641, Kingdom of Saudi Arabia) 146, 565 (1987)

Sonographic demonstration of portal venous gas in necrotizing enterocolitis. Robberecht, E.A. et al. (Children's Hosp. "C. Hooft", Univ. Med. School, De Pintelaan 185, B-9000 Gent, Belgium) 147, 192 (1988)

The acrocallosal syndrome. Philip, N. et al. (Inserm U.242 et Centre de Génétique Méd., Hôpital d'Enfants de la Timone, F-13385 Marseille Cedex 5, France) 147, $206(1988)$

European Journal of Radiology (Stuttgart)

Acute renal failure in children. Vergesslich, K. A et al. (Dept. of Paed. Univ. Hosp. of Vienna, Waehringer Guertel 18-20, A-1090 Vienna, Austria) 7, $263(1987)$

Liquid crystal thermography in the localization of undescended testicles. Göblyös, P., Szüle jr., E. (Postgraduate Med. Univ., Dept. of Rad., H-1389 Budapest P.O.B. 112, Hungary) 7, 266 (1987)

Fortschritte auf dem Gebiete der Röntgenstrahlen und der Nuklearmedizin (Stuttgart)

Stadieneinteilung der hämophilen Osteoarthropathie mit dem PetterssonScore. Erlemann, R. et al. (Inst. für Klinische Rad. der Westf. WilhelmsUniv., Albert Schweitzer-Str. 33, D-4400 Münster, FRG) 147, 521 (1987)

Sonographische und phlebographische Abklärung einer unklaren Schwellung im Bereich des Mons pubis. Weiss, H. et al. (Röntgendiagn. Zen-

tralinst. LKH, St. Veiterstr. 47, A-9020 Klagenfurt, Austria) 147, 577 (1987)

Sonographische Befunde der Gallenblase bei Patienten mit Mukoviszidose. Winkielman, J. et al. (Univ.-Klinik für Kinder- und Jugendmed., Hufelandstr. 55, D-4300 Essen, FRG) 147, 632 (1987)

Bedeutung der Kernspintomographie für die Diagnostik von Knochenmarkserkrankungen im Kindesalter. Reither, M. et al. (Rad. Zentrum, Abt. Diagnostik, Städt. Klinikum, Flurstr. 17, D-8500 Nürnberg 91, FRG) 147,647 (1987)

Klinische Pädiatrie (Stuttgart)

Die kranio-zerebrale Dysproportion - ein Beitrag zur Bedeutung extrazerebraler Flüssigkeitsansammlungen im Säuglingsalter. Bode, $\mathbf{H}$., Straßburg, H.M. (Univ.-Kinderklinik, Mathildenstr.1, D-7800 Freiburg i. Brsg., FRG) 199, 399 (1987)

Postoperative sonographische Verlaufsuntersuchungen von Hirntumoren im Kindesalter. Dittrich, M. et al. (Univ-Kinderklinik, Langenbeckstr.1, D-6500 Mainz, FRG) 199, 403 (1987)

Aseptische Knochennekrosen als Spätkomplikation nach erfolgreicher Behandlung von Leukämien und schwerer aplastischer Anämie. Slavc, I. et al. (Univ.-Kinderklinik, Auenbruggerplatz, A-8036 Graz, Austria) 199, 449 (1987)

Idiopathische juvenile Osteoporose-Bericht über zwei Fälle. Rosskamp, $\mathbf{R}$. et al. (Univ.-Kinderklinik, Adenauerallee 119, D-5300 Bonn 1, FRG) 199, 457 (1987)

Two new cases of thrombocytopenia absent radius (TAR) syndrome: Clinical, genetic and nosologic features. Giuffrè, $L$. et al. (Ist. MaternoInfantile Univ., Via Cardinale Rampolla, I-Palermo, Italy) 200, 10 (1988)

Klinische Relevanz des Trachealbronchus. Herrmann, N. et al. (Strüther Berg 7b, D-8800 Ansbach, FRG) 200, 20 (1988) 